\title{
THE ROLE OF COMPARATIVE PEDAGOGY IN EVALUATING EDUCATION SYSTEMS OF DIFFERENT COUNTRIES
}

\begin{abstract}
The article presents the definition of comparative pedagogy according to comparisons from different parts of the world. The subject of the pedagogical sub-disciplinary study, which in its own particular way relates to the research method, has been presented. The obtained results provide the basis for the argument that the scope of comparative pedagogy is quite extensive. In addition, over the years, it has widened considerably. The vocational comparative pedagogy has been added to the traditional direction of comparative pedagogy. Its indispensable function has been the analysis of the economic processes in close connection with the problems of preparation and improvement of the qualifications of personnel. Therefore, comparative pedagogy does not currently have a theory of one kind that definitively determines its subject matter. The author points out that not only the didactic system itself, but also the various conditions that support or inhibit educational activity, are important for comparability. This article also describes the objectives of comparative pedagogy. It has been found that the cognitive goal is to explore the knowledge of education systems and to compare the qualitative and quantitative changes in these systems. The practical aim is to borrow and introduce theoretical and/or practical solutions into the didactic system. On the other hand, the educational goal is to determine and improve the actual educational situation. Based on the collected materials, it has been concluded that both the objectives and the subject matter of comparative pedagogy research are very broad and often go beyond the area of the pedagogical sub-discipline.

Keywords: education system, comparative pedagogy, subject of comparative pedagogy, objectives of comparative pedagogy.

\section{INTRODUCTION}

The concept of "comparative pedagogy" has a broad palette of definitions that are similar to each other, sometimes supplementing each other and sometimes quite different. To this day, no definitive definition of comparative pedagogy has been formulated.

According to the American comparator, "comparative pedagogy is the analysis of systems and problems of pedagogy in two or more countries, in the context of their historical, socioeconomic, political, cultural, religious and other significant determinants" (Průcha, 2004, p. 32).

In the scientific works it has been also pointed out that comparative pedagogy as a discipline is intended to verify the current development trends of education in a larger area of states, to combine theory with practice and social education with society (Průcha, 2004).

The German comparator has proposed to specify the working area of comparative pedagogy. The scholar claims that comparative pedagogy is a synergy between Academic comparative education and interventionist comparative education (Prücha, 2004).
\end{abstract}


The diversity of concepts points to the fact that the definition of comparative pedagogy is multidimensional definition (Chepil, 2014; Sbruieva, 1999; Halus, Shaposhnikova, 2006).

Therefore, the following questions arise: what is the subject of comparative pedagogy in modern times? What are the aims of comparative pedagogy?

\section{THE AIM OF THE STUDY}

The purpose of the study is to present the area of the activities of comparative pedagogy.

The task is to define the subject and the objectives of this pedagogical sub-discipline, and to try to determine its directions of development both in the present and in the future.

\section{THEORETICAL FRAMEWORK AND RESEARCH METHODS}

In many European countries, the concepts of comparative pedagogy have influenced the education system of a given country. They also supported the reorganization of the education systems in Poland and Ukraine.

The subject matter of comparative pedagogy in the evaluation of the Polish education system has been presented in numerous scientific papers. They described the development of the Polish education system and analyzed the process of creating it in different time periods (Furmanek, 2010). Many times the national educational system has been compared with the Western European school system and new methods of teaching and educating young people have been analyzed (Dziewulak, 1997; Jałmużny, Leżańska, 2002).

Academic backgrounds supported the concept that "comparative pedagogy is one of the tools of educational policy" and gave this pedagogical discipline "a specific scientific and practical status that distinguishes it from other pedagogical sciences" (Suchodolski, 1972, p. 25). In the papers it has been also pointed out that "if we use the common divide between the two traditional streams of comparative pedagogy: the first stream pays homage to the concept of pure science, and the second one is seeking to validate discipline through its usefulness for practice, it turns out that in Poland this second understanding has been accepted" (Pachociński, 2007, p. 54).

It can be concluded that the influence of comparative pedagogy on the Polish education system has led to the fact that in the process of systemic transformation in Poland, national education has been oriented and rebuilt in the model of Western European countries (Włoch, 2016).

Comparative pedagogy has also played an important role in evaluating the Ukrainian education system and helped to reorganize it.

In Ukrainian scientific publications it has been emphasized that the task of this pedagogical sub-discipline is to describe and analyze education systems in the present or in the past, taking into account all external and internal factors such as culture, tradition, religion, political or economic system (Chepil, 2014; Sbruieva, 1999; Halus, Shaposhnikova, 2006).

Looking through the prism of comparative pedagogy, it has been also recognized the correlation between social changes and educational changes, and it was noted that "the changes of the social system, especially the radical changes, must naturally bring about changes in the education and training system" (Nyczkało, Szlosek, 2008, p. 36).

While reforming the education system of Ukraine, the experience of other nations and the specificity of their own country has been taken into account.

The ways of knowing and explaining certain facts from the past or present are different. It can be said that the study of certain facts or their separate phenomena has its own way or research method. According to the accepted assumptions, "the research method is a system of logical thinking, expressed in a scientific approach to solving specific problems" (Maszke, 2008, p. 157). 
In this theoretical study, a comparative method has been used. About the significant role of this method it was written: "(...) in some sciences, comparison is a cognitive activity that is extremely important and occurs in the first set of research, as well as observation in observational methods. That is why some teachings, such as comparative linguistics, comparative psychology and comparative zoology are called comparative" (Pieter, 1967, p. 127).

When describing the role of comparative pedagogy in evaluating education systems, it should be noted that the subject matter of the study is particularly related to the research method.

\section{RESULTS}

Comparative pedagogy describes problems that are the subject of other sciences, and therefore the scope of comparative pedagogy is very broad (Nawroczyński, 1972). In Polish scientific circles it is considered that the subject of comparative pedagogical studies is actually all pedagogical issues in which knowledge of the state of things may be helpful in solving similar educational problems in other countries (Suchodolski, 1985).

The author of the work Comparative Pedagogy, proposes to divide comparative pedagogy by reference to the subject of the study into historical comparative pedagogy and the pedagogy of spatial comparisons (Frątczak, 1993).

One of the Ukrainian pedagogues points out that the terms "comparative pedagogy" and "foreign pedagogy" should be distinguished. According to the author, the goal of foreign pedagogy is to collect and describe facts that reflect the state of education in a given country. Therefore, foreign pedagogy is descriptive. On the other hand, for comparative pedagogy the main objective is to reveal the global regularity of the development of the didactic system. It should also take into account the specificities of education in different countries (Vasiuk, 2008).

Another Polish pedagogue presents the peculiar views on the subject of comparative pedagogy. He writes that the mentioned science does not seek the object of research, and that object creates itself. He also points out that we currently do not have one type of theory that could be used to describe the subject of comparative pedagogy. "Rather it should be said that there are many theories with varying degrees of application that are equally well suited for this purpose. It is to be expected that many such theories will arise in the future. In this sense, those who think that the subject of comparative pedagogy is quite extensive are right and that comparative research can be equally well carried out in areas traditionally reserved for pedagogy, pedeutology, andragogy and many others" (Pachociński, 2000, p. 96).

Over the years, the subject of comparative pedagogy has expanded. For comparative purposes, not only the didactic system itself and its results, but also the various conditions that supported or inhibited its activity, became important. More and more attention was paid to the educational aspect. In the scientific papers the need to consider in the comparative studies of all genetic and functional determinants has been highlighted. Based on this view, it has been argued that "for comparative pedagogy, it is not important that there are different phenomena, but rather the way in which they originate - what are their origins and how they appear in historical development and in some concrete reality" (Wiloch, 1970, p. 186).

It is worth stressing that in the papers describing the theoretical foundation of comparative pedagogy there is still a debate underway verifying the subject of pedagogy of comparative study.

Despite such a broadly understood subject of comparative pedagogical research and the different and even extreme and contradictory views described in pedagogical literature, comparative pedagogy is developing and occupying an important place among other 
scientific disciplines. Today, as in the past, it still continues to set goals and objectives. According to the accepted concept the goals of comparative pedagogy can be divided into: cognitive goals; practical goals; educational goals (Frątczak, 1993).

The subject matter of objectives of comparative pedagogy appears in numerous scientific papers. According to one of the authors by comparing the education system in one country but at different historical periods, we are aware of the magnitude of progress, we get to know the qualitative and quantitative changes that have taken place in this system, thus achieving the goal - cognitive goal (Pęcherski, 2000).

Next to the cognitive goal, utilitarian purposes (practical) count. One component of this objective may be providing objective information about the learning process in different countries or providing valuable material to improve the education system. "If the purpose of educational policy in a country is to promote secondary education, comparative educational research will help answer the question: what school system and what organizational structure of education is more effective in achieving this goal? What factors and conditions - including extracurricular -conduce and what inhibits the achievement of such school system goals" (Pęcherski, 2000, p. 85).

The Czech pedagogue also writes about the practical orientation of comparative pedagogy. The author points out that "the traditional idea that comparative pedagogy works exclusively with pedagogical theorists is no longer justified. On the contrary, today the achievement of this science is also used by employees in other disciplines of knowledge, officials, politicians and educators" (Průcha, 2004, p. 20).

We are inclined to believe that the utilitarian purpose of comparative pedagogy is also to borrow and introduce proven theoretical and/or practical solutions for both secondaryschool education and vocational education (Nychkalo, 2011). The inspiration for this opinion has been drawn from the work of a Ukrainian pedagogue who emphasizes that "comparative pedagogy as a pedagogical sub-discipline (...) is related to the specifics of vocational training in various economic and education systems on the basis of their close connection. As a result, professional comparative pedagogy cannot be limited only to analyzing educational processes in different countries or regions of the world. Its indispensable function is the analysis of economic processes (macro- and microeconomic) in the conditions of individual states (...) in close relation to the problems of preparation and improvement of the qualifications of personnel at various stages of socio-economic development" (Nyczkało, 2011, p. 41).

The child-rearing aspect of comparative pedagogy has also become important. By presenting the didactic system as a component of two processes: teaching-learning and being raised within academic circles it has been noted that "comparative pedagogy as a discipline that evaluates educational phenomena from various systems of reality, specifically determining educational processes, must cover a very broad range of pedagogical issues, in order not to omit some relationships in educational realities which has significant pedagogical importance" (Wiloch, 1970, p. 180).

Based on the presented material it has been stated that both the aims and the subject matter of research in comparative pedagogy are very broad and often go beyond the field of pedagogical sciences.

The above reflections on the concept of comparative pedagogy, the subject matter and the purpose of its research can be summarized by the words of the Polish scholar who writes about the importance of pedagogical comparative research: “(...) in comparative research, the most important thing is to know more about education in other countries 
(especially our neighbors), focus attention on the most valuable achievements (learn from others) to properly promote their own models of educational activities in other countries and to build theoretical foundations of mechanisms for growth of achievement in the various fields of effect in education and to create links that are conducive to shape the compatibility of education systems in many European countries and similarly in some global solutions" (Niemiec, 2011, p. 24).

\section{CONCLUSIONS}

The comparative analysis of Czech, German, Polish and Ukrainian source materials describing the role of comparative pedagogy in evaluating different education systems gives the basis for arguing that the scope of this sub-discipline is very extensive. Sometimes comparative pedagogy studies the objects traditionally included in other pedagogical subdisciplines. Therefore, its future is shaping such directions as comparative pedagogy of preschool education, comparative pedagogy of general education, professional comparative pedagogy, comparative pedagogy of higher education and others.

The broad scope of comparative pedagogical activities explains why the subject of research and the aims of this sub-discipline today are not definitively defined. It can be assumed that they will never be unambiguously defined, as the development of science will continue to widen.

\section{REFERENCES}

1. Chepil, M. M. (2014). Porivnialna pedahohika. Vziato z http://academiapc.com.ua/product $/ 373$.

2. Dziewulak, D. (1997). Systemy szkolne Unii Europejskiej. Warszawa: Wydawnictwo Akademickie "Żak".

3. Frątczak, J. (1993). Pedagogika porównawcza: teksty, opracowania i zadania. Bydgoszcz: Wydawnictwo Uczelniane WSP.

4. Furmanek, W. (2010). Edukacja a przemiany cywilizacyjne. [Education and Civilization Transformations].Wydawnictwo Oświatowe, Rzeszów (in Polish).

5. Halus, O. M., \& Shaposhnikova, L. M. (2006). Porivnialna pedahohika. Vziato z http:/www.studfiles.ru/preview/5110225/

6. Jałmużny, T., Leżańska, W., (2002). Szkolnictwo niepubliczne w Polsce $i w$ Europie $w X X$ wieku. [Non-public Education in Poland and in Europe in the 20th century].Wydawnictwo Wyższa Szkoła Informatyki, Łódź (in Polish).

7. Maszke, A.W. (2008). Metody i techniki badań pedagogicznych. Rzeszów: Wydawnictwo Uniwersytetu Rzeszowskiego.

8. Nawroczyński, B. (1972). Przedmiot i metoda pedagogiki porównawczej. In M. Pęcherski (Ed.), Studia pedagogiczne (pp. 9-11). Wrocław-Warszawa-Kraków-Gdańsk: Wydawnictwo PAN.

9. Niemiec, J. (2011). Szczególne znaczenie badań porównawczych dla pedagogiki. In F. Szlosek (Ed.), Badanie Dojrzewanie Rozwój (na drodze do doktoratu). Wybrane aspekty badań komparatystycznych: założenia metodologiczne i analizy porównawcze (p. 24). Warszawa-Radom: Wydawnictwo Naukowe Instytutu Technologii Eksploatacji - PIB.

10. Nyczkało, N. (2011). Komparatystyka w kontekście procesów globalizacji i procesów integracyjnych. In F. Szlosek (Ed.), Badanie Dojrzewanie Rozwój (na drodze do doktoratu). Wybrane aspekty badań komparatystycznych: założenia metodologiczne i analizy porównawcze (p. 41). Warszawa-Radom: Wydawnictwo Naukowe Instytutu Technologii Eksploatacji - PIB. 
11. Nychkalo, N. H. (2011). Teoretyko-metodolohichni zasady porivnialnoi profesiinoi pedahohiky. Vziato z http:/www.khnu.km.ua/root/res/2-7001-11.pdf.

12. Nyczkało, N., \& Szlosek, F. (2008). Ksztatcenie zawodowe w Polsce i Ukrainie na tle przemian. Warszawa-Radom: Wydawnictwo Naukowe Instytutu Technologii Eksploatacji Państwowego Instytutu Badawczego.

13. Pachociński, R. (2000). Przedmiot pedagogiki porównawczej. In R. Leppert (Ed.), Edukacja w świecie wspótczesnym. (p. 54). Kraków: Oficyna wydawnicza "Impuls".

14. Pachociński, R. (2007). Pedagogika porównawcza. Warszawa: Wydawnictwo Akademickie "Żak".

15. Pęcherski, M. (2000). Pojecie, cele i procedura badawcza oświatowych badań porównawczych. In R. Leppert (Ed.), Edukacja w świecie wspótczesnym. (p. 85). Kraków: Oficyna wydawnicza "Impuls".

16. Pieter, J. (1967). Ogólna metodologia pracy naukowej. Wrocław-WarszawaKraków: Zakład Narodowy Imienia Ossolińskich Wydawnictwo Polskiej Akademii Nauk.

17. Průcha, J. (2004). Pedagogika porównawcza. Podręcznik akademicki. Warszawa: Wydawnictwo Naukowe PWN.

18. Sbruieva, A. A. (1999). Porivnialna pedahohika. Vziato z http://www.studfiles. ru/preview/2040660/.

19. Suchodolski, B. (1972). Pedagogika porównawcza i polityka oświatowa. In M. Pęcherski (Ed.), Studia pedagogiczne (p. 25). Wrocław-Warszawa-Kraków-Gdańsk: Wydawnictwo PAN.

20. Suchodolski, B. (1985). Pedagogika. Podręcznik dla kandydatów na nauczycieli. Warszawa: Państwowe Wydawnictwo Naukowe.

21. Vasiuk, O. V. (2008). Porivnialna pedahohika. Vziato z http://www.studfiles. $\mathrm{ru} /$ preview/3540566/.

22. Wiloch, T. J. (1970). Wprowadzenie do pedagogiki porównawczej. Warszawa: Państwowe Wydawnictwo Naukowe.

23. Włoch, A. (2016). Edukacja europejska: założenia, perspektywy, funkcje społeczne: krytyczne spojrzenie. Kraków: Wydawnictwo Uniwersytet Pedagogiczny im. Komisji Edukacji Narodowej. 